VOX PATRUM $32(2012)$ t. 58

Ks. Marcin WYSOCKI*

\title{
„KTÓRYŻ TO NAPÓJ, JEŚLI NIE NAPÓJ MĄDROŚCI, JEST RADOŚCIĄ SERCA?" (EP. 1, 7), CZYLI JAK OPISUJE RADOŚĆ ŚW. AMBROŻY W SWOICH LISTACH
}

Św. Augustyn przyznaje się w swoich Wyznaniach do tego, że gdy przybył w 384 r. do Mediolanu i spotkał się z biskupem Ambrożym, na początku nie zauważył w życiu Biskupa Mediolanu nic nadzwyczajnego. Co więcej zwrócił uwagę tylko na zewnętrzny wymiar jego życia, pozostawiając to, co wewnętrzne:

„Ambroży wydawał mi się po prostu człowiekiem, któremu się w świecie bardzo dobrze powiodło. [...] Co się zaś tyczyło wewnętrznej nadziei tego człowieka, walki, jaką toczył przeciwko niebezpieczeństwom związanym z tak wysoką pozycją życiową, pociech, jakie znajdował wśród przeciwności losu, wreszcie radości, jaka mu rozgrzewała samą głębię serca, gdy karmił się Twym Chlebem - tego zupełnie się nie domyślałem, bo przekraczało to moje doświadczenie" 1 .

Minęło trochę czasu zanim Augustyn dostrzegł i wewnętrzne cechy Mediolańczyka. Dostrzegł również radość, która musiała zajmować w życiu Ambrożego ważne miejsce skoro na nią zwrócił po latach uwagę Biskup Hippony. Była ona wyjątkowa, bo jak podkreśla to Augustyn, wypływała z przyjmowania Ciała Chrystusa. Nie jest celem tego artykułu opisywanie tych właśnie radości, bo zostało to uczynione gdzie indziej², ale zbadanie, co o radości mówił Biskup Mediolanu do adresatów swych listów, w jaki sposób przedstawiał im radość i jak ją określał. Ambroży nie pozostawił po sobie traktatu dotyczącego radości, taki traktat nie został też napisany przez żadnego z Ojców Kościoła, jednak nie można z tego wnioskować, że nie przywiązywali oni do radości

*Ks. dr Marcin Wysocki - adiunkt w Katedrze Patrologii Greckiej w Instytucie Historii Kościoła i Patrologii na Wydziale Teologii Katolickiego Uniwersytetu Lubelskiego Jana Pawła II; e-mail: mwysocki@kul.lublin.pl.

${ }^{1}$ Augustinus, Confessiones VI 3, PL 32, 720: ,[...] Ambrosium felicem quendam hominem secundum saeculum opinabar [...].quid autem ille spei gereret, et adversus ipsius excellentiae temptamenta quid luctaminis haberet quid ve solaminis in adversis, et occultum os eius, quod erat in corde eius, quam sapida gaudia de pane tuo ruminaret, nec conicere noveram nec expertus eram”, thum. Z. Kubiak: Św. Augustyn, Wyznania, Kraków 1994, 115-116.

${ }^{2}$ Por. A. Fitzgerald, La dynamique de la joie chez Ambroise de Milan, CPE 93 (2004) 11-23. 
żadnej uwagi. Wprost przeciwnie, nie tylko w licznych traktatach (głównie egzegetycznych), ale również w ich codziennym życiu radość chrześcijańska odgrywała znaczącą rolę, jak o tym świadczą chociażby apoftegmaty Ojców pustyni. Wydaje się, że szczególnym rodzajem pism, w którym radość ta była wyartykułowana, są listy, jako najbardziej bezpośrednie, dotyczące codziennego życia i poruszające najszersze spektrum spraw pisma wczesnochrześcijańskich pisarzy. Dlatego wydaje się celowym zbadać bogatą spuściznę epistularną biskupa Ambrożego, którego - jak zaznaczono na początku słowami św. Augustyna - przenikał szczególny rodzaj radości: płynący z posilania się Ciałem Chrystusa. Radość ta musiała w życiu i twórczości Ambrożego znajdować odzwierciedlenie i przedłużenie. Radością tą musiał się też dzielić z innymi i wydaje się, że właśnie listy były najlepszą do tego drogą.

\section{1. „Ciesząc się największym szczęściem i dobrobytem” (Ep. 11 [extra} coll.], 17) - radość ziemska. Rozważania o radości w listach św. Ambrożego należy rozpoczać od przedstawienia ziemskiej radości, którą Biskup dostrzegał wokół siebie i innym ją zalecał. Była to radość, której powodem były codzienne doczesne wydarzenia. W sposób szczególny Ambroży doceniał i radował się obecnością drugiego człowieka. Odczuwał radość nie tylko z jego fizycznej obecności, ale również - co w przypadku prowadzonych tu analiz jest bardzo ważne - z prowadzonej z nim korespondencji. W liście do konsula Antoniusza wyraźnie to stwierdzał:

„Sprawia mi radość spotykać się z Tobą w ten sposób; bo Twój list powoduje, że lękam się otwarcie rozmawiać z nierozłącznym [towarzyszem] mej duszy"3.

Radość z wymiany listów była według Ambrożego jeszcze większa, gdy list doręczany był przez przyjaciół. Radość z otrzymywania listu jest wtedy, według Biskupa, podwajana, jak pisał do papieża Syrycjusza ${ }^{4}$. W ciekawy sposób Ambroży thumaczy się wobec biskupów Fegadiusza i Delfina oraz okazuje radość z wymiany listów, ponieważ Polibiusz, który miał dostarczyć do nich list, oczekiwał dwóch listów po jednym dla każdego z nich, tymczasem Ambroży podyktował i zaadresował jeden list do obu odbiorców. Wobec zdziwienia Polibiusza w kolejnym liście thumaczy się Ambroży w następujący sposób:

„Powiedziałem mu, że list był zaadresowany do was obydwu zgodnie z naszym zwyczajem, ponieważ wasz święty duch raduje się nie z liczby listów, lecz z połączenia imion, i nie można dopuścić, aby zostały rozdzielony imio-

${ }^{3}$ Ambrosius, Epistula 60, 3, ed. G. Banterle, SAEMO 20, Milano - Roma 1988, 144: „His te cum delectat congredi; nam litterae tuae, ut aperte cum individuo pectoris mei loquar, verecundari me faciunt", thum. P. Nowak: Ambroży z Mediolanu, Listy, II, BOK 20, Kraków 2003, 93.

${ }^{4}$ Por. tenże, Epistula 46, 1, SAEMO 20, 70, BOK 20, 36. 
na tych, których zjednoczyło uczucie; a nasz urząd tego wymaga, abyśmy streszczali się przy wyrażaniu miłości"'.

W kontekście tej wypowiedzi widać zatem, że nie tyle same listy i ich liczba, ale więź łącząca korespondujące strony ma zasadnicze znaczenie w odczuwaniu radości z wymiany listów.

Listy, które sprawiały tyle radości Ambrożemu, także w swej treści niosły radość z ziemskich wydarzeń. Wydarzenia, które sprawiały radość Biskupowi Mediolanu i jego interlokutorom często dotyczyły ziemskiego wymiaru działalności Kościoła. W liście skierowanym do konsula Tacjana Ambroży wyraża radość z przyjaźni, która łączy go z prefektem pretorium Rufinem, ale także z tego, że został on wyniesiony na wyższe stanowisko ${ }^{6}$. Z wyniesienia do godności biskupiej cieszył się Ambroży w innym liście, skierowanym do Anyzjusza. Ambroży wskazuje w nim, że cierpi i smuci się z powodu śmierci biskupa Acholiusza, ale jednocześnie cieszy się, że jego następcą i dziedzicem na stolicy biskupiej w Tessalonikach został właśnie Anyzjusz, uczeń Acholiusza ${ }^{7}$. Dla Ambrożego jako biskupa i człowieka odpowiedzialnego za prowincję kościelną radością były więc także te wydarzenia doczesne, które sprawiały, że Kościół trwał i miał wciąż nowych pasterzy.

Kolejną na tym świecie, dotyczącą Kościoła, radością Ambrożego, jako obrońcy ortodoksji i jednego z głównych przeciwników arianizmu, była oczywiście radość z tego, że ortodoksja zwycięża a arianizm ponosi klęski. W liście synodalnym z Akwilei, w którym Biskup Mediolanu wyraża troskę nie tylko o Kościół w Italii, ale również we wschodniej części Cesarstwa, gdzie arianizm był bardzo silny, okazuje radość z odzyskania przez ortodoksyjnych wiernych zagarniętych przez arian kościołów:

„[...] dowiedzieliśmy się z największą zatem radością i weselem, że we wschodnich częściach [cesarstwa] - po wyrzuceniu arian, którzy przemoca przywłaszczyli sobie kościoły - święte świątynie Boże są nawiedzane przez samych tylko katolików"8.

Warto zwrócić uwagę na swoiste stopniowanie radości w tej wypowiedzi. Biskup pisze, że odzyskanie świątyń przez katolików było dla niego największą radością i weselem (summo gaudio atque laetitia). Wydaje się to tym bardziej

${ }^{5}$ Tenże, Epistula 47, 2, SAEMO 20, 72: „Dixi ad utrumque vestrum datam more usu que nostro, eo quod sancta mens vestra non epistularum numero, sed coniunctione nominum delectaretur, nec perpeti posset, ut fieret vocabulorum separatio, quorum affectus conveniret, id que praescriptum nostro muneri, ut uteremur caritatis compendio", BOK 20, 37.

${ }^{6}$ Por. tenże, Epistula 45, 1, SAEMO 20, 68, BOK 20, 35.

${ }^{7}$ Por. tenże, Epistula 52, 1, SAEMO 20, 92, BOK 20, 50.

${ }^{8}$ Tenże, Epistula 6 [extra coll.], 3, ed. G. Banterle, SAEMO 21, Milano - Roma 1988, 202: ,[...] cognovimus quidem summo gaudio atque laetitia eiectis Arrianis, qui ecclesias violenter invaserant, sacra dei templa per solos catholicos frequentari”, tłum. P. Nowak: Ambroży z Mediolanu, Listy, III, BOK 28, Kraków 2012, 161. 
zrozumiałe, jeżeli przypomni się o trudnościach i smutkach, które były udziałem Ambrożego w Mediolanie podczas sporu o świątynie chrześcijańskie, które zagarnęli arianie ${ }^{9}$. W innym Liście, będącym relacją naszego Biskupa o tych wydarzeniach przekazaną siostrze Marcelinie, oddaje on radość wiernych z decyzji cesarza o oddaniu świątyni katolikom:

„Jaka wówczas była radość całej ludności, jaki aplauz całego ludu, jaka wdzięczność!"”10

Inną troską biskupa Ambrożego była jedność Kościoła, która sprawiała mu zarówno radość, jak i smutek. W liście do cesarza Teodozjusza Ambroży wraz z innymi biskupami Italii podkreśla, że Kościoły Afryki i Galii „cieszą się zgodną wspólnotą wszystkich biskupów"11. Zgoda biskupów, trwanie w jedności jest więc powodem radości nie tylko Ambrożego, ale przede wszystkim tych partykularnych Kościołów. W następnym jednak zdaniu Ambroży przedstawia sytuację przeciwną, która istnieje pomiędzy Kościołem Wschodu i Zachodu i która jest - jak się wydaje - powodem smutku: ,aby na synodzie były znane te przyczyny, które zakłóciły naszą komunię ze Wschodem, i by został usunięty wszelki niepokój" ${ }^{12}$. Z pewnością usunięcie tych przeszkód prowadzić będzie do radości, podobnej do tej, która była powodowana jednością Kościołów Afryki i Galii.

Z widzialnym życiem Kościoła związany jest jeszcze jeden objaw radości, który przywołuje w swoich listach św. Ambroży. W innym liście, skierowanym do siostry Marceliny, opisującym odnalezienie relikwii świętych męczenników Protazego i Gerwazego, Ambroży ukazuje ogromną radość z powodu ich odkrycia oraz cuda i znaki, które działy się podczas uroczystej procesji w której przeniesiono ciała męczenników do kościoła; w końcowym fragmencie swego opisu Biskup podkreśla radość z możliwości dotknięcia się przez wiernych relikwii:

„Dowiedzieliście się - co więcej, sami zobaczyliście - że wielu zostało uwolnionych od demonów; bardzo wielu także - gdy tylko dotknęli rękami szaty świętych - zostali uwolnieni od tych słabości, na które cierpieli; widzicie, że

\footnotetext{
${ }^{9}$ Por. L. Cracco Ruggini, Ambrogio a le opposizioni anticattoliche fra il 383 e il 390, „Augustinianum" 14 (1974) 409-449; G. Nauroy, Le fouet et le miel. Le combat d'Ambroise en 386 contre l'arianisme milanaise, RechAug 23 (1988) 3-86; T.D. Barnes, Ambrose and the Basilicas of Milan in 385 and 386: The primary documents and their implications, ZACh 4 (2000) 282-299; M. Colish, Why the Portiana?: Reflections on the Milanese Basilica Crisis of 386, JECS 10 (2002) 361-372.

${ }^{10}$ Ambrosius, Epistula 76, 26, SAEMO 21, 152: „Quae tunc plebis totius laetitia fuit, qui totius populi plausus, quae gratia!", BOK 28, 106.

${ }^{11}$ Tenże, Epistula 8 [extra coll.], 3, SAEMO 21, 216: „[...] Gallia atque Africa, quae omnium sacerdotum concordi societate potiuntur", BOK 28, 171.

${ }^{12}$ Tenże, Epistula 8 [extra coll.], 3, SAEMO 21, 216: ,[...] sed ut ea, quae communionem nostram de orientis parte turbaverunt cognoscerentur in synodo et omnis e medio scrupulus tolleretur", BOK 28, 171.
} 
odnowiły się cuda dawnych czasów, w których przez przyjście Pana Jezusa rozlała się na ziemi większa łaska; widzicie, że bardzo wielu zostało uzdrowionych jakby przez cień świętych ciał. Ileż chusteczek nieustannie się narzuca, ileż ubrań [kładzie się] na te najświętsze relikwie, i odbiera się je przez samo dotknięcie [obdarzone] mocą uzdrawiającą! Wszyscy pragną dotknąć (gaudent omnes) ich choćby najdalszego krańca, a kto ich dotknie, będzie uzdrowiony"13.

Nie jest tu więc ukazana radość Ambrożego, ale radość ludzi, którzy doświadczają łask od Boga za pośrednictwem św. Protazego i Gerwazego. Radość wiernych z dokonujących się cudów, z odnalezienia relikwii, objawia się w prostym oddawaniu czci relikwiom. Jest to radość Kościoła, który przyzywa swoich świętych protektorów i na sposób doczesny cieszy się z ich ziemskiej obecności wśród wiernych ${ }^{14}$. Jednak ogromne zaangażowanie Ambrożego, wielokrotne powracanie w listach do tych wydarzeń, dzielenie się nimi w szczegółach przede wszystkim z siostrą, wskazują na wielką radość, która była również udziałem Ambrożego, a nie tylko mediolańskiego ludu.

Musimy pamiętać, że Ambroży był zaangażowany w życie polityczne i społeczne ówczesnego świata, zarówno jako zarządca prowincji Ligurii i Emilii, jak i powołany na katedrę biskupią w Mediolanie. Życie polityczne i społeczne było więc częścią jego codziennej działalności, przynoszącą zarówno radości, jak i smutki. W listach nie znajdujemy wielu odniesień dotyczących radości w tych właśnie sferach. Ważne jest jednak, że te fragmenty, które odnoszą się do sfery polityki państwowej, świeckiej, mają również odniesienie do sfery eklezjalnej i dotyczą dwóch najważniejszych chyba wydarzeń pontyfikatu Ambrożego dziejących się na styku państwa i Kościoła - kwestii świątyń mediolańskich zagarniętych przez arian oraz rzezi w Tessalonikach. Radość z odzyskania świątyni została przedstawiona powyżej, tu warto przyjrzeć się kwestii radości w kontekście wypadków w Tessalonikach. Wydaje się dziwne, że Ambroży w tak tragicznym kontekście w ogóle używa terminologii związanej z radością, jednak spojrzenie na nią w kontekście ,polityki” pastoralnej Ambrożego wyjaśnia zasadność użycia tych słów ${ }^{15}$. Odnoszą się one do cesarza Teodozjusza, który był sprawcą masakry w Tessalonikach, w której zginęło siedem tysięcy osób. List powstał wkrótce po tych wydarzeniach, w sierpniu

${ }^{13}$ Tenże, Epistula 77, 9, SAEMO 21, 158: „Cognovistis immo vidistis ipsi multos a daemoniis purgatos, plurimos etiam ubi vestem sanctorum manibus contigerunt his quibus laborabant debilitatibus absolutos, reparata vetusti temporis miracula, quo se per adventum domini Iesu gratia terris maior infuderat, umbra quadam sanctorum corporum plerosque sanatos cernitis. Quanta oraria iactitantur, quanta indumenta super reliquias sacratissimas et tactu ipso medicabilia reposcuntur! Gaudent omnes extrema linea contingere et qui contigerit salvus erit”, BOK 28, 111-112.

${ }^{14} \mathrm{O}$ kulcie relikwii u Ambrożego por. R. Andrzejewski, Kult relikwii wedlug św. Ambrożego, AK 93 (1979) 64-72.

${ }^{15} \mathrm{Na}$ temat działalności pastoralnej w kontekście polityki por. J. Pałucki, Święty Ambroży jako duszpasterz w świetle ekshortacji pastoralnych, Lublin 1996, 65-72 i 196-197. 
390 roku. Ambroży był głęboko przekonany o swoim obowiązku napomnienia błądzącego cesarza i dlatego wzywa go do pokuty, ale jednocześnie zdaje on sobie sprawę, że Teodozjusz ma pełnię władzy i nic nie zapowiada, że zmieni się to w najbliższym czasie. Dlatego też u końca swego listu Ambroży stosuje swoiste captatio benevolentiae. Po ostrych słowach i argumentach Biskup Mediolanu przechodzi na ton pojednawczy:

„Obyś zażywał, czcigodny cesarzu, razem z twymi świętymi synami trwałego spokoju, ciesząc się największym szczęściem i dobrobytem"16.

Ambroży życzy więc cesarzowi radości ze szczęścia i dobrobytu, ale jednocześnie stawia twarde warunki tej radości - pokuta i zadośćuczynienie. $Z$ nich płynąć ma radość samego Ambrożego, o której wspomina on w nieco wcześniejszym fragmencie tego samego listu:

„Złożysz swą ofiarę wtedy, gdy otrzymasz pozwolenie na składanie ofiary, gdy twoja ofiara będzie przyjemna Bogu. Czyż nie byłbym zadowolony ciesząc się łaskawością cesarza, tak iż postąpiłbym według twojej woli, gdyby sytuacja na to pozwalała?"'17

Ambroży zdaje sobie sprawę, że stawiając twarde warunki cesarzowi może narazić się na jego niełaskę. Mógłby nie zwrócić cesarzowi uwagi, pominąć milczeniem jawną zbrodnię i nieprawość i czerpać radość oraz profity z takiego postępowania. Jednak wydaje się, że byłaby to radość fałszywa, prawdziwą bowiem radość Biskup posiadł, gdy mógł powitać pojednanego z Kościołem imperatora w drzwiach świątyni.

W listach Ambrożego odnajdujemy jeszcze jedno nawiązanie do radości w kontekście spraw doczesnych, a konkretnie rolnictwa. W dwóch listach 24. i 36. - Biskup Mediolanu wskazuje na radość, którą może dawać praca na roli. Obie wypowiedzi osadzone są jednak w głębszym kontekście. W pierwszym przypadku, w liście do biskupa Marcelego, Ambroży porusza sprawę nieporozumień wokół pola, które Marceli zapisał swojej siostrze, a które po jej śmierci miało przejść na własność Kościoła. Takiemu zarządzaniu ojcowizną sprzeciwił się Letus, brat Marcelego, domagając się swojego udziału w majątku. W liście, który jest cennym świadectwem wprowadzonego przez Konstantyna Wielkiego prawa episcopalis audientia, św. Ambroży przyznał Letusowi prawo własności, a w zamian zobowiązał go do corocznego dostarczania siostrze ustalonej ilości plonów. W kontekście takiej decyzji Ambroży pisał do Marcelego:

${ }^{16}$ Ambrosius, Epistula 11 [extra coll.], 17, SAEMO 21, 240: „Beatissimus et florentissimus cum sanctis pignoribus fruaris tranquillitate perpetua, imperator auguste”, BOK 28, 189.

${ }^{17}$ Tenże, Epistula 11 [extra coll.], 15, SAEMO 21, 238: „Tunc offeres cum sacrificandi acceperis facultatem, quando hostia tua accepta sit deo. Nonne me delectaret habere gratiam imperatoris, ut secundum voluntatem tuam agerem, si causa pateretur?", BOK 28, 188-189. 
„Letus będzie uprawiał ziemię dla siostry, której przedtem odmawiał cudzej pracy. Letus będzie zbierał żniwo dla siostry, dla której przedtem nie mógł znieść cudzych darów. Zwiezie plony do spichlerzy twojej siostry i radosny to będzie czynił, uzyskawszy już także przepisanie własności na swoje imię"18.

Radość przynoszą zatem według Biskupa: uprawa ziemi i czerpanie z niej plonów, którymi Letus będzie mógł się dzielić z siostrą oraz posiadanie własnej ziemi. Ambroży zwraca zatem uwagę również na radość, którą można czerpać z codziennej pracy i świadczenia dobra drugiemu człowiekowi, ale także z rzeczy doczesnych.

Drugi z listów - skierowany do biskupa Konstancjusza - jest w istocie podręcznikiem postępowania biskupa, zawierającym wskazówki w wypełnianiu tego urzędu. Obok poruszanych wielu kwestii dyscyplinarnych, moralnych i duszpasterskich biskup Ambroży zawiera w liście również takie wskazania:

„A ponieważ użyliśmy przykładu z pola, nakazuj im zachowywać nienaruszone prawa graniczne, strzec granic [ustalonych przez] ojców, których chroni prawo. Często od braterskiej miłości ważniejsza jest życzliwość sąsiada: tamten bowiem często jest daleko, a ten w pobliżu jest świadkiem całego [twojego] życia, naocznym świadkiem postępowania. Niech cieszy się, że może swobodnie wypuścić bydło na tereny graniczne i leżąc na zielonej trawie zażywać beztroskiego odpoczynku" 19 .

Ambroży zaleca, aby cieszyć się z poprawnych relacji międzysąsiedzkich, które przejawiają się w bezkonfliktowym korzystaniu z pastwisk i pól. Radością ma być sławiony przez wielu starożytnych poetów odpoczynek na łonie przyrody, w bukolicznym krajobrazie.

Z powyższych wypowiedzi naszego Biskupa wynika, że nie były mu obce również ziemskie radości i doceniał ich wagę w życiu człowieka. Ukazują, że Ambroży potrafił radować się doczesnością i zachęcał innych do czerpania z niej radości oraz wskazywał na elementy codziennego życia: prywatnego, społecznego, państwowego, kościelnego, które mogły przynieść taką radość.

2. „Bóg, twój Bóg, namaścił ciebie olejkiem radości” (Ps 45, 8; Ep. 7, 29) - radość duchowa. Jednak najważniejsze i najliczniejsze odniesienia w listach św. Ambrożego dotyczą oczywiście radości duchowej, niezwiązanej

${ }^{18}$ Tenże, Epistula 24, 12, ed. G. Banterle, G. SAEMO 19, Milano - Roma 1988, 244: „Arabit Laetus sorori, cui ante alienos invidebat labores. Messem Laetus sorori colliget, in qua ante ferre non poterat alienas donationes. Deferet fructus ad sororis horrea et hoc laetus faciet recepta iam etiam nominis sui proprietate", tłum. P. Nowak: Ambroży z Mediolanu, Listy, I, Kraków 1997, BOK 9, 188.

${ }^{19}$ Tenże, Epistula 36, 30, SAEMO 20, 40: „Et quia de agro exemplum sumpsimus, praecipe illis inviolata confinii servare iura, paternos custodire terminos, quos lex tuetur. Supra fraternam caritatem frequenter est vicini gratia; ille enim saepe longe, hic in proximo est vitae omnis testis, conversationis arbiter. Delectet eum per finitima spatia laxare liberum pecus et in herba viridi proiectum secura captare otia”, BOK 20, 18-19. 
ze sprawami tego świata. Radości dotyczącej spraw Bożych, która jest charakterystyczna dla chrześcijan i która płynie z Boga i z obcowania z Nim.

Ambroży przede wszystkim podkreśla w swych listach zasadniczą odmienność radości ziemskiej i duchowej, pogańskiej i chrześcijańskiej. W liście skierowanym do kapłana Ireneusza, interpretując historię Lei, Racheli oraz Labana i jego synów, wkłada w usta Jakuba następującą odpowiedź Labanowi:

„Lecz jak byś mnie odprawił? Czy z twoim weselem, które jest pełne smutku, to znaczy z bębenkami i piszczałkami grającymi zbyt hałaśliwie, i przy słodkich dźwiękach lutni nieprzyjemnie dudniących, przy dźwiękach fałszowanych, odgłosach nieartykułowanych, głosach niemych, cymbałach raniących duszę? Wierzyłeś, że mógłbym mieć w tym upodobanie, tym być przywołany z powrotem? To są rzeczy, od których uciekłem i nie boję się złości twoich słów. Uciekłem, aby takie rzeczy mi nie towarzyszyły, abym odszedł nie zabierając niczego z twojego mienia"20.

Ambroży ukazuje w tym fragmencie ową zasadniczą różnicę radości ziemskiej i duchowej - radość ziemska jest hałaśliwa, raniąca dusze, a przede wszystkim fałszywa. I na to Ambroży zwraca nade wszystko uwagę. W innych listach podkreśla, że taką fałszywą radość posiadają wrogowie Chrystusa, Kościoła i ortodoksji. W liście skierowanym do cesarza Teodozjusza w związku z wypadkami w Callinicum w Syrii, Ambroży, chcąc uchronić mnichów i biskupa przed kara, zwraca się z retorycznymi pytaniami do cesarza:

„Taką radość, cesarzu, dasz wiarołomcom? Takie świętowanie Synagodze, takie zasmucenie Kościołowi?’”21

O takiej złej radości pisał również Ambroży w liście do cesarza Walentyniana w obronie katolickich kościołów Mediolanu przed wydaniem ich w ręce arian:

„Cóż bowiem innego bardziej ich raduje niż słyszeć o znieważaniu Chrystusa?

Cóż innego może im się bardziej podobać niż to - co nie daj Boże - że zaprzecza się bóstwu Chrystusa? Z nimi zupełnie dobrze zgadza się arianin, który twierdzi, że Chrystus jest stworzeniem, co także poganie i Żydzi od razu chętnie przyznają"22.

${ }^{20}$ Tenże, Epistula 4, 12, SAEMO 19, 56: „Sed quomodo me dimisisses? An cum laetitia tua, quae plena est maestitudinis, cum tympanis scilicet adque organis inmoderata modulantibus et sonis tibiarum suavibus insuavia resultantibus, sonis dissonis, crepitibus discrepantibus, vocibus mutis, cymbalis animam ferientibus? His me delectari posse credidisti, his revocari? Haec sunt, quae ego fugi, nec vereor verborum tuorum invidiam. Fugi, ne me talia sequerentur, ne quid de tuis accipiens abirem", BOK 9, 54.

${ }^{21}$ Tenże, Epistula 74, 20, SAEMO 21, 98: „Haec gaudia, imperator, perfidis? Hanc celebritatem synagogae, hos luctus ecclesiae?", BOK 28, 65.

${ }^{22}$ Tenże, Epistula 75, 13, SAEMO 21, 110-112: „Quid illos aliud nisi Christi iniuriam audire delectat? Quid illis aliud potest placere nisi, quod absit, ut Christi divinitas denegetur? Cum his pla- 
Z obu tych wypowiedzi widać jasno, że Ambroży wskazuje na istnienie radości niewłaściwej, która ma na celu wyśmiewanie się z wiary katolickiej i która jest charakterystyczna dla wrogów Chrystusa i Kościoła. Ich radość staje się w konsekwencji smutkiem Kościoła.

Jednak Kościół nie jest przepełniony smutkiem sui generis. Kościół ma przede wszystkim powody do radości, a tylko niekiedy - jak widać to było powyżej - do smutku. Ambroży wielokrotnie w swoich listach podkreśla właśnie radość Kościoła jako wspólnoty wierzących, jako wspólnoty, która gromadzi się w świątyniach, by celebrować dni święte. O takiej radości, cytując Psalm 30, pisał Ambroży do swojej siostry Marceliny, opisując radość z odzyskania bazyliki przeznaczonej dla arian. Biskup radując się, dziękował Chrystusowi, że On sam wybawił lud swój ${ }^{23}$.

Świątynie są miejscem celebracji i z posiadania ich należy się radować, ale to w określone dni gromadzi się w nich Kościół, aby radować się obecnością i działaniem Boga. Spośród listów Ambrożego szczególne znaczenie w kwestii celebrowania dni Pańskich ma List 13. [extra coll.] napisany przez Biskupa Mediolanu na prośbę cesarza Teodozjusza Wielkiego w celu ustalenia daty obchodzenia Wielkanocy. Wielokrotnie w tym swoistym traktacie o celebrowaniu Paschy mowa jest o radości. Opowiadając się za świętowaniem Paschy w niedzielę Ambroży wskazuje, że właśnie ten dzień jest w sposób szczególny przeznaczony do radości:

„Paschę należy spożywać z goryczą, to jest $\mathrm{z}$ bólem - jako że z tak wielkim świętokradztwem został zabity Autor zbawienia ludzi - prorok poucza, że w dzień Pański natomiast należy się radować, mówiąc: «Oto jest dzień, który Pan uczynił: radujmy się w nim i weselmy!» (Ps 118, 24)”24.

Należy według Biskupa Mediolanu zachowywać i dzień Męki i dzień Zmartwychwstania, aby doświadczać zarówno goryczy i cierpienia, jak i radości, która ma być pokrzepieniem i umocnieniem chrześcijan celebrujących zmartwychwstanie Pana i wyjście Ludu Wybranego z Egiptu ${ }^{25}$. Co ważne, Ambroży wskazuje, że Ojcowie - żyjący wcześniej biskupi i pisarze kościelni - dają przykład, aby radośnie i z weselem obchodzić święto powszechnego zbawienia $^{26}$. Radość jest więc przekazywana w pewien sposób w Kościele, ta prawdziwa radość była zawsze taka sama, niezależnie od wieku i czasu.

ne bene convenit Arriano qui creaturam Christum dicit, quod etiam gentiles ac Iudaei promptissime confitentur", BOK 28, 75.

${ }^{23}$ Por. tenże, Epistula 76, 21, SAEMO 21, 148, BOK 28, 103-104.

${ }^{24}$ Tenże, Epistula 13 [extra coll.], 11, SAEMO 21, 252: ,[...] pascha edendum cum amartitudine hoc est cum dolore. quod tanto sacrilegio hominum auctor salutis sit interemptus, die autem dominica exultandum propheta docet dicens: «Hic est dies quem fecit dominus, exultemus et laetamur in eo»", BOK 28, 198.

${ }^{25}$ Por. tenże, Epistula 13 [extra coll.], 12. 20, SAEMO 21, 252-253, 260, BOK 28, 198-199, 202.

${ }^{26}$ Por. tenże, Epistula 13 [extra coll.], 22, SAEMO 21, 260-262, BOK 28, 203-204. 
Prawdziwa chrześcijańska radość ma zawsze i wszędzie ten sam przedmiot celebrowanie obecności Boga wśród swego ludu.

Jednak szczególnym powodem do radości Kościoła - w myśl słów Chrystusa (Mt 18, 13; Łk 15, 7. 10) - jest przede wszystkim przebaczenie, odpuszczanie grzechów i nawracanie się grzeszników. W Liście 2. [extra coll.] Ambroży pisał do cesarza Teodozjusza podejmując tematykę radości ziemskich i duchowych:

„Życzę ci jednak dalszego wzrastania w pobożności - gdyż z cnót, które Pan ci dał, żadna jej nie przewyższa - aby przez twoją łaskawość Kościół Boży, jak raduje się z pokoju i pogody niewinnych, tak cieszył się również z przebaczenia [udzielonego] winnym. Daruj przede wszystkim tym, którzy zawinili także przeciw tobie" ${ }^{27}$.

List odnosi się do przebaczenia, którego cesarz powinien udzielić pokonanym zwolennikom Eugeniusza. Jednak Biskup nie pozostawia tej sprawy tylko w wymiarze świeckim, ale odnosi ją do rzeczywistości duchowej i Kościoła. Wygrana w bitwie jest sprawą polityki, ale przebaczenie jest częścią chrześcijańskiego, pobożnego życia cesarza i sprawą Kościoła, który ma prawo cieszyć się z przebaczenia, którym obdarowano Jego dzieci.

Wyższą formą przebaczenia i większym powodem do radości jest oczywiście przebaczenie grzechów i odkupienie, do czego Kościół został powołany. W liście do swej siostry Marceliny Ambroży przytacza swoje kazanie wygłoszone w obecności cesarza po wspomnianych już wydarzeniach w Callinicum. W końcowym fragmencie Biskup tak mówił do Teodozjusza:

„I dlatego miłując Jego Ciało - to jest Kościół - daj wodę Jego nogom, ucałuj Jego nogi, tak abyś nie tylko uwolnił tych, którzy zostali pochwyceni na grzechu, lecz także obdarował ich twym pokojem i darował im [kary dla] zgody i spokoju. Wylej wonny olejek na Jego nogi, aby cały dom, w którym Chrystus zasiada do stołu, napełnił się twoim wonnym olejkiem, a wszyscy zasiadający razem z Nim cieszyli się z twoich woni. Tak czyni ten, kto szanuje ostatnich, a z odpuszczenia ich win aniołowie radują się tak jak «z jednego grzesznika» (Łk 15, 10) czyniącego pokutę, weselą się Apostołowie, cieszą się prorocy. «Nie mogą bowiem oczy powiedzieć ręce: 'Nie jesteś nam potrzebna', albo głowa nogom: 'Nie potrzebuję was'» (1Kor 12, 21). Skoro więc wszyscy są potrzebni, chroń całe ciało Pana Jezusa, aby także On strzegł twojego królestwa swoją niebiańską łaskawością"28.

${ }^{27}$ Tenże, Epistula 2 [extra coll.], 7, SAEMO 21, 192: „Opto tamen tibi etiam atque etiam incrementa pietatis, qua nihil dominus praestantius dedit, ut per tuam clementiam ecclesia domini sicut innocentium pace et tranquillitate gratuletur ita etiam reorum absolutione laetetur. Ignosce maxime his qui etiam in te peccaverint", BOK 28, 152.

${ }^{28}$ Tenże, Epistula 1 [extra coll.], 26, SAEMO 21, 186: „[...] et ideo corpus eius hoc est ecclesiam diligendo aquam da pedibus eius, osculare pedes eius ut non solum absolvas eos qui in peccatis 
Ambroży przenosi więc wydarzenie polityczne, społeczne na grunt duchowy, do sfery wiary i religii. Odpuszczenie win, darowanie kar jest powodem radości Kościoła, z nich radują się aniołowie, Apostołowie, prorocy - tak wielka jest radość $z$ darowania win.

Ta szczególna więź - w radości - Kościoła ziemskiego i Kościoła niebiańskiego uwidoczniona została również w liście do Oroncjana (Ep. 21), dotyczącym natury duszy i jej niebiańskiego pochodzenia. Wśród posług, które spełniają aniołowie, Ambroży wymienia również szczególną łączność z Kościołem ziemskim - aplikację kar i plag. Jednak Biskup wyraźnie zaznacza, że aniołowie posiadając szczęśliwe życie woleliby wieść je raczej w spokoju niż niepokoić się wymierzaniem kar za grzechy, woleliby raczej radować się z nawrócenia niż płakać z powodu grzechów:

„Albowiem ci, którzy «radują się z odkupienia jednego grzesznika» (Łk 15, 10), z całą pewnością wzdychają z powodu nieszczęść tylu grzeszników”29.

Radość nie obca jest więc i aniołom, którzy partycypują w radościach i smutkach, a przede wszystkim radują się z odkupienia choćby jednego grzesznika, co powinno być również radością ziemskiego Kościoła.

Radość z odpuszczenia grzechów, którego doświadcza człowiek, winna być według Ambrożego przekazywana dalej, do innych ludzi. Powinna być udzielana innym poprzez darowanie im ziemskich win. W przywoływanym już tutaj liście do siostry Marceliny, Ambroży zwraca uwagę, że tak jak my cieszymy się darowaniem naszych win, tak również inni powinni się z tego cieszyć doznając od nas przebaczenia przewinieńn ${ }^{30}$.

Zbawienie, odkupienie, przebaczenie grzechów jest głównym powodem radości. Dlatego w jednym z listów Ambroży wzywał, ukazując tak naprawdę model doskonałego chrześcijanina:

„Co najważniejsze, nawróćcie się wszyscy do Pana Jezusa. Niech będzie w was radość z tego życia z czystym sumieniem, oczekiwanie śmierci z nadzieją nieśmiertelności, pewność co do zmartwychwstania z łaską Chrystusa, prawda z prostota, wiara z ufnością, powściagliwość ze świętością, pracowi-

\footnotetext{
deprehensi sunt verum etiam pace tua dones concordiae et quieti relaxes. Mitte unguentum in pedes eius ut tota domus in qua Christus recumbit tuo repleatur unguento, omnes recumbentes cum eo gaudeant tuis odoribus; sic est qui honorat ultimos, quorum absolutione gaudeant angeli sicut super uno peccatore poenitentiam agente, laetentur apostoli, delectentur prophetae. Non enim possunt dicere oculi manui: Operam tuam non desideramus, aut caput pedibus: Non estis mihi necessarii. Ergo quia omnes necessarii sunt, tuere omne corpus domini Iesu, ut ipse quoque regnum tuum caelesti sua dignatione custodiat", BOK 28, 133.

${ }^{29}$ Tenże, Epistula 21, 10, SAEMO 19, 218: „Etenim qui 'gaudent unius peccatoris redemptione', utique tantorum peccatorum aerumnis ingemescunt”, BOK 9, 171.

${ }^{30}$ Por. tenże, Epistula 1 [extra coll.], 8, SAEMO 21, 176, BOK 28, 125.
} 
tość z trzeźwością, obcowanie [z innymi] ze skromnościa, wykształcenie bez próżności, trzeźwość wiernej nauki bez oparów herezji”’31.

Nawrócenie jest więc punktem wyjścia, z niego mają wypływać inne cnoty, w tym radość z życia po nawróceniu, z czystym już sumieniem. W liście do Oroncjana (Ep. 18) Ambroży w retorycznej formie wypowiedzi duszy porusza również kwestię radości spowodowanej nawróceniem. Tym razem jednak słowa duszy wskazują na radość Odkupiciela:

„Zniosę gniew Pana, który albo karci mnie upadłą, albo tobie dał władzę udręczenia mnie, ponieważ zgrzeszyłam; zniosę jednak, aż rozsądzi moją sprawę. Jeśli bowiem nie wyznam i nie zapłacę ceny moich grzechów, nie będę mogła być usprawiedliwiona. Gdy zaś zostanę usprawiedliwiona, płacąc podwójnie za grzechy, On poprowadzi moją sprawę, odkładając swe zagniewanie, gdyż zostało zadośćuczynione wyrokowi, wyprowadzi mnie do światła, abym ujrzała sprawiedliwość Jego i oglądała Jego radość"’32.

Radość $\mathrm{z}$ odkupienia, z nawrócenia, z odpuszczenia win, jest więc nie tylko cechą ludzi, lecz także aniołów, a nawet samego Boga - Odkupiciela.

W powyższym fragmencie cytowanego listu, Ambroży słowami duszy wskazywał na oglądanie radości Zbawiciela, na przebywanie z Nim w Jego światłości i sprawiedliwości. Nie może więc w epistolografii ambrozjańskiejjako odzwierciedleniu poglądów chrześcijanina i biskupa - zabraknąć również wskazania na radość płynącą z obecności Boga. W Liście 13. Biskup Mediolanu, omawiając kwestie wiary, przedstawia w ujęciu historycznym wierność Bogu za pomocą obrazu duszy. Naród Wybrany, powołany do wiary wcześniej, jest duszą, która jest godna opłakiwania, bo utraciła Oblubieńca, utraciła dary i cnoty. Jest godna opłakiwania, bo utraciła radość bycia z Oblubieńcem. Pisał bowiem Ambroży do Ireneusza:

„I dlatego nakazuje płakać nad tą duszą. Jak bowiem powinni radować się i świętować ci, z którymi jest Oblubieniec, tak samo ta dusza, której został wyrwany Oblubieniec, musi płakać, jak jest napisane w Ewangelii o Apostołach, że «kiedy zabiorą im pana młodego, wtedy będą pościć» $(\mathrm{Mt} 9,15) \mathrm{w}$ owych

${ }^{31}$ Tenże, Epistula 14 [extra coll.], 113, SAEMO 21, 320: „Ad summam convertimini omnes ad dominum Iesum. Sit in vobis vitae huius delectatio in bona conscientia, patientia mortis cum spe immortalitatis, confirmatio resurrectionis cum Christi gratia, veritas cum simplicitate, fides cum confidentia, abstinentia cum sanctitate, industria cum sobrietate, conversatio cum modestia, eruditio sine vanitate, sobrietas doctrinae fidelis sine haeresis temulentia”, BOK 28, 247.

${ }^{32}$ Tenże, Epistula 18, 21, SAEMO 19, 192: „Iram domini sustinebo, qui vel lapsam castigat vel tibi potestatem adfligendi dedit, quia peccavi; sustinebo tamen, donec iustificet causam meam. Nisi enim confessa fuero et exsolvero praetia iniquitatum mearum, non potero iustificari. Cum autem fuero iustificata solvens duplicia peccata, educet iudicium meum deponens indignationem, quia satisfactum sententiae est, educet me ad lumen, ut videam iustitiam eius et aspiciam delectationem eius", BOK 9, 154. 
dniach. Przeto i ta dusza miała przedtem radość i wesele, kiedy miała «dziewicze Słowo». I dlatego nie pościła, gdyż były to dni świętowania i pokrzepienia, jako że był obecny Oblubieniec, przynosząc tym, u których przebywał, z niezmierną obfitością wielkie bogactwo niebieskiego Pokarmu i strumienie wina, co rozwesela serca ludzkie. Lecz po tym, jak przez swoje czyny utraciła Oblubieńca, każe się jej we włosiennicy czynić pokutę za swoje grzechy i opłakiwać samą siebie, ponieważ umarł dla niej Chrystus, który jest «dziewiczym Słowem», ukrzyżowany za nią"33.

Przebywanie z Chrystusem, wierność Jego Ewangelii w codziennym życiu i postępowaniu są powodem do radości. Radość jest swoistym nakazem dla chrześcijanina, wypływającym z dobrego życia i bycia z Bogiem. Są jednak według Ambrożego również tacy, którzy powinni płakać i smucić się, bo przez swe złe czyny utracili Chrystusa, który daje radość. Co więcej Chrystus chroni tych, którzy wytrwali przy Nim, walczy o nich, a ,jako zwycięzca i kochający oblubieniec obdarza radością i łaską" ${ }^{34}$. W takim rozumieniu chrześcijańskiej radości można dostrzec jej ziemski wymiar, jednak Ambroży wie, że pełnię tej radości można osiagnąć dopiero w eschatologicznym spełnieniu. W tej ostatecznej radości, we wspólnocie odkupionych, uczestniczyć będzie całe stworzenie wolne od marności i zepsucia:

„Całe zaś mogłoby wzdychać nie przez swoje, lecz przez nasze cierpienia i «rodzić w boleściach» może owego Ducha zbawienia, Ducha radości, oczekując «przybrania za synów» (Rz 8, 23) Bożych, aby dostąpić wspólnego wesela i radości z odkupienia rodzaju ludzkiego"35.

Radość tę osiagnąć będzie można w eschatonie, jak wskazano powyżej, za dobre czyny i życie z Chrystusem. Stworzenia i potęgi niebieskie w nadziei oczekują na ten moment radości, a wraz z nimi również ludzie, którzy obecnie

${ }^{33}$ Tenże, Epistula 13, 2-3, SAEMO 19, 144: „Et ideo lamentandum praecipit pro ea anima. Nam sicut illis gratulandum et epulandum est, cum quibus sponsus est, ita illi animae lugendum, cui sponsus fuerit ereptus, sicut de apostolis scriptum est in evangelio quoniam cum auferetur ab his sponsus, tunc ieiunabunt in illis diebus. Ergo et haec anima habebat ante laetitiam et exultationem, cum haberet «parthenicon logon». Et ideo non ieiunabat, quia dies erant epularum et refectionis, cum adesset sponsus, invehens, quibus aderat, ubertatis affluentia caelestis alimenti copias, vini rigatus, quo «corda hominum laetificantur». Sed posteaquam sponsum factis amisit suis, iubetur in cilicio agere paenitentiam peccatorum suorum et deflere semetipsam, quia mortuus est ei crucifixus pro ea Christus, qui est «parthenicos logos»", BOK 9, 118-119.

${ }^{34}$ Tenże, Epistula 13, 10, SAEMO 19, 148: ,[...] quasi victor et diligens sponsus iucunditatem confert et gratiam", BOK 9, 121.

${ }^{35}$ Tenże, Epistula 22, 2, SAEMO 19, 220: „Omnis autem congemescat, non in suo, sed in nostro labore et 'conparturiat' illum fortasse spiritum salutis, spiritum iucunditatis, expectans adoptionem filiorum dei, ut communem de redemptione humani generis consequatur laetitiam et exultationem", BOK 9, 172. 
znoszą niewolę i cierpienia oraz pocieszają się, aby później się radować36. W Liście 19., będącym kontynuacją wykładu o wierze z Listu 18., Ambroży zajmuje się tymi, którzy trwają w Kościele. Wobec rzeczywistości ostatecznej wyróżnia dwie grupy: tych, którzy grzeszyli i tych, którzy wytrwali w wierności Chrystusowi. O ile tym pierwszym - którzy nawracają się w momencie śmierci - Ambroży przyznaje tylko „mieszkanie w raju” (incolatum paradisi), o tyle tym drugim - którzy ćwiczyli się w cnocie, walczyli dla Chrystusa, nawracali pogan, ofiarowywali się za Chrystusa - przyznaje królestwo Boże i radość z otrzymanego wynagrodzenia (se remuneratione donatum gaude$a t)^{37}$. Ten, który rozwijał swoją wiarę, rozbudzał w sobie miłość Chrystusa w przejściu z tego świata doświadcza radości i wesela i do owego królestwa Bożego wstępuje bez przeszkód podziwiany przez moce niebios ${ }^{38}$. Co więcej, aniołowie cieszą się, gdy do nieba wstępuje święty i wierny człowiek, jak pisał Ambroży pocieszając wspólnotę kościelną w Tessalonikach po zmarłym biskupie Acholiuszu ${ }^{39}$.

W przywołanym powyżej Liście 4., Ambroży ustami Lei i Racheli wskazuje wyraźnie, że źródłem prawdziwej radości, w przeciwieństwie do radości ziemskiej, nie są: towarzystwo, pożądanie, bogactwo i rozpusta. Są to rzeczy i radości bezwartościowe, nędzne i ubogie ${ }^{40}$. Ci, którzy podążają za takimi radościami, według Biskupa Mediolanu używającego biblijnych porównań, nie zbiorą owoców swoich zasiewów, utracą zbiory i nie znajdą pożywienia, a wycisnąwszy oliwki, nie będą mieli olejku radości, ani nie będą pili wina wesela ${ }^{41}$. Jest jednak na to recepta - nawrócenie i pokładanie ufności w Bogu. Chrystus bowiem przyszedł na ten świat

„aby obudzić to życie ze snu i pouczyć, że snem jest ten rodzaj życia, w którym różne zmiany następują po sobie jak pijane, i nie widząc nic pewnego ani stałego - jak by to był sen śpiącego - [w rzeczywistości] nie widzimy, i słysząc nie słyszymy, i jedząc nie sycimy się, radując nie doznajemy radości, biegnąc nie osiagamy celu. Próżne są nadzieje ludzi na tym świeci, gdyż sądza, że powinni iść za rzeczami, które nie istnieją, tak jakby istniały"42.

Można więc powiedzieć, że radość ziemska jest tylko snem, złudną radością,

\footnotetext{
${ }^{36}$ Por. tenże, Epistula 21, 11, SAEMO 19, 220, BOK 9, 171.

${ }^{37}$ Por. tenże, Epistula 19, 9, SAEMO 19, 200, BOK 9, 159.

${ }^{38}$ Por. tenże, Epistula 54, 4, SAEMO 20, 100, BOK 20, 64.

${ }^{39}$ Por. tenże, Epistula 51, 8, SAEMO 20, 88, BOK 20, 47.

${ }^{40}$ Por. tenże, Epistula 4, 9, SAEMO 19, 54-56, BOK 9, 53.

${ }^{41}$ Por. tenże, Epistula 18, 20, SAEMO 19, 190-192, BOK 9, 153.

42 Tenże, Epistula 36, 22, SAEMO 20, 34-36: ,[...] ut vitam hanc de somno resuscitaret et somnium esse hunc vivendi usum doceret, in quo diversae commutationum vices tamquam ebriae et nihil solidum, nihil firmum, tamquam dormientis somnium videntes non videmus et audientes non audimus et manducantes non satiamur, gratulantes non gratulamur, currentes non pervenimus. Vanae spes hominum in hoc saeculo, qui ea quae non sunt, tamquam quae sint, sequenda arbitrentur", BOK $20,15$.
} 
która nie daje prawdziwej radości, a Chrystus budzi do prawdziwej radości i rozświetla ciemności owego snu ${ }^{43}$. Gwarantem prawdziwej radości jest Bóg, Jego polecenia, Jego wyrocznie i Jego przykazania ${ }^{44}$. Oglądanie i przebywanie z Bogiem nie powinno być powodem strachu, ale radości i wydarzeń pomyślnych ${ }^{45}$.

Ambroży w swych listach ukazuje również, co może zdziałać prawdziwa radość i jakie są jej efekty. Przywołując postać Hioba, Biskup podkreślił, że on jak każdy prorok „,nie zwracał uwagi na rzeczy cielesna, lecz na duchowe” i dlatego „był obnażony, lecz nie wstydził się, gdyż był pełen wesela i radości duchowej”"46. Radość prawdziwa pozwala inaczej spojrzeć na świat i jego wymagania. Prawdziwa chrześcijańska radość pokonuje ziemskie konwenanse i pseudoradości. Chrześcijaństwo, które nie jest tylko filozofią i próżnymi słowami, zaprawiało w cnotach i dawało wyjątkową moc i radość, jak w przypadku świętych męczennic Tekli, Agnieszki i Pelagii, które wysławiał Ambroży podkreślając, że „pośród lwów dziewica się radowała i nieustraszona spoglądała na ryczące bestie" ${ }^{47}$. Biskup Mediolanu zwracał uwagę, że w sposób szczególny radość posiadają dwa stany życia chrześcijańskiego: mnisi i dziewice, a więc ci, którzy pozbywają się rzeczy cielesnych, pozbywają się „radości” tego świata. W Liście 14. [extra coll.], skierowanym do wspólnoty Kościoła w Vercelli, Ambroży porusza między innymi kwestię życia mniszego. Porównuje życie światowe i życie mnicha używając antytez:

„Zatem to [życie] toczy zaciętą walkę, tamto się usuwa; to zwycięża ponęty, tamto [od nich] ucieka; to triumfuje nad światem, tamto się raduje; dla tego świat jest ukrzyżowany, a ono dla świata, tamtemu jest on nieznany; to znosi wiele pokus, i dlatego większe jest jego zwycięstwo, dla tamtego rzadsze są upadki, łatwiej mu się ich ustrzec" ${ }^{\prime 4}$.

Istnieje zatem w myśli Ambrożego, przywołane już powyżej, zasadnicze przeciwieństwo życia światowego i życia mniszego. Życie mnisze jest powodem radości, choć to życie światowe triumfuje i jest łatwiejsze, nie owocuje jednak w ostateczności radością. W Liście 57. dotyczącym sprawy zawistnie oskarżonej i osądzonej dziewicy, Ambroży również podkreśla wyzbycie się przez

${ }^{43}$ Por. tenże, Epistula 18, 20, SAEMO 19, 190-192, BOK 9, 153.

${ }^{44}$ Por. tenże, Epistula 4, 6, SAEMO 19, 54, BOK 9, 52.

${ }^{45}$ Por. tenże, Epistula 62, 12, SAEMO 20, 152, BOK 20, 103.

${ }^{46}$ Tenże, Epistula 27, 12, SAEMO 19, 258: „Ille enim non corporalibus intendebat, sed spiritalibus. [...] Noe nudatus erat, sed non erubescebat, quia erat plenus iucunditatis et spiritalis laetitiae", BOK 9, 200-201.

${ }^{47}$ Tenże, Epistula 7, 36, SAEMO 19, 92: ,[...] inter leones virgo exultavit et rudentes bestias spectavit intrepida", BOK 9, 81.

${ }^{48}$ Tenże, Epistula 14 [extra coll.], 74, SAEMO 21, 300: „Haec ergo dimicat, illa se removet, haec illecebras vincit, illa refugit, huic mundus triumphatur, illi exultat, huic mundus crucifigitur vel ipsa mundo, illi ignoratur, huic plura temptamenta et ideo maior victoria, illi infrequentior lapsus, facilior custodia", BOK 28, 233. 
kobiety oddające się dziewiczemu życiu przywilejów - w tym sądowych a jednocześnie wskazuje na cześć jaką posiada stan dziewictwa i radość z niego płynącą ${ }^{49}$.

Oczywiście Ambroży w swoich listach znacznie częściej porusza tematykę radości. Czasami, nie w sposób systematyczny, mówi o radości, którą odznaczać się winni chrześcijanie. Na przykład we wspomnianym powyżej Liście 14. [extra coll.], pośród licznych wskazówek dla chrześcijańskich stanów, poruszając ulubiony przez siebie motyw przeciwieństwa życia ziemskiego $\mathrm{i}$ życia duchowego, Biskup zaleca pocieszanie pogrążonych w żałobie i wskazuje, że lepsza jest żałoba niż światowa radość, która jest powodem upadku i ostatecznie pozostaje bez nagrody ${ }^{50}$. Radość ziemska w przeciwieństwie do radości duchowej jest tylko chwilowa, krótkotrwała, tak jak to opisuje Biskup w Liście 29., w którym ukazuje radość intelektu z poznania świata. W piękny, obrazowy sposób Ambroży ukazuje w nim piękno i wielkość Bożego stworzenia, a jednocześnie potęgę ludzkiego intelektu. Zwraca jednak uwagę, że jest to tylko chwilowe oszołomienie podziwem niebieskich gwiazd i chwilowa radość z blasku ich światel ${ }^{51}$.

Według Biskupa Mediolanu wielu ludzi jest jednak tylko zewnętrznie, fałszywie radosnych, a jednocześnie są oni zamknięci na łaskę, a co za tym idzie również na prawdziwą radość:

„Lecz szukajmy dla siebie drogi niedostępnej dla słów zarozumialców, nieprzebytej dla uczynków ludzi niedoświadczonych, której nie podeptał nikt skalany, oczywiście skalany brudami swojego lenistwa, poplamiony błotem nieprawości i - jakby przez ciemności i ruiny swojej duszy - chylący się do upadku, ponieważ nie zakosztował żadnej słodyczy cnoty, albo w każdym razie uważał, że raczej należy patrzeć na nią z ukosa, niż przyjąć ją prostym uczuciem i otwartymi ramionami umysłu, i który - jak to lubi wielu takich, którzy uważają się za dowcipnych i pełnych humoru, przemieniając piękno mądrości w hańbę przewrotności - nie widząc prawdziwej łaski, tak samo, jak ktoś pogrążony w ciemności nie wierzy żyjącym w dziennym świetle" ${ }^{92}$.

Ludzie fałszywie radośni przemieniają piękno mądrości w hańbę przewrotności. Na mądrość w radości zwraca uwagę Ambroży również w będącym

\footnotetext{
${ }^{49}$ Por. tenże, Epistula 57, 1, SAEMO 20, 124, BOK 20, 80.

${ }^{50}$ Por. tenże, Epistula 14 [extra coll.], 106, SAEMO 21, 318, BOK 28, 245.

${ }^{51}$ Por. tenże, Epistula 29, 15, SAEMO 19, 282, BOK 9, 216-217.

${ }^{52}$ Tenże, Epistula 6, 3, SAEMO 19, 66: „Sed quaeramus nobis viam inaccessam sermonibus insolentium, inviam operibus inperitorum, quam nullus maculosus deterat, maculosus scilicet ignaviae suae sordibus et fimo iniquitatis oblitus tenebris que et parietinis quibusdam animae ruinosus, qui nullam virtutis suavitatem gustaverit, aut certe limis eam spectandam magis quam directo adfectu et aperto sinu mentis suscipiendam arbitratus sit, et - quod plerique amant, qui sibi faceti adque urbani videntur pulchritudinem sapientiae in dedecus versutiae transfigurantes - veram non intuens gratiam tamquam in nocte positus non credit in die viventibus", BOK 9, 61.
} 
częścią tytułu fragmencie Listu 1. adresowanego do biskupa Lyonu Justusa, w którym wyjaśnia on znaczenie dwudrachmy ofiarowanej jako „okup za życie" (Wj 30, 12-13). Biskup podkreśla, że z mądrości płynie radość serca. Mądrości, której dawcą jest Bóg i która wlana jest do naszych zmysłów, myśli i namiętności ${ }^{53}$.

Jak wynika z powyższych analiz listów św. Ambrożego, prezentuje on w nich szerokie i głębokie rozważania dotyczące radości. Odzwierciedleniem tego bogactwa jest z pewnością słownictwo, którego Biskup Mediolanu używał na opisanie fenomenu radości. Różnorodność podejmowanej tematyki, kontekstu i źródeł radości wskazują na znaczenie radości w życiu i twórczości Biskupa Mediolanu. Docenia on radość ziemską, czerpaną z codziennego zwykłego życia, ale ponad nią przedkłada radość duchową, ową „radość serca" (iucunditas cordis), która płynie z Boga, dawcy mądrości.

\section{„FOR WHAT IS THE JOY OF THE HEART BUT THE DRAUGHTS OF WISDOM?" $(E P .1,7)$ - ABOUT HOW AMBROSE OF MILAN DESCRIBED A JOY IN HIS LETTERS}

\section{(Summary)}

This article presents the concept of joy in surviving more than 90 letters of St. Ambrose of Milan. As it is clear from the above analysis of St. Ambrose's letters, he included in them broad and deep reflections on a joy. Certainly the vocabulary that was used by Bishop of Milan to describe the phenomenon of joy reflects the richness of this phenomenon. The variety of topics, context, sources of joy prsented in his letters show the importance of joy in the life and work of the Bishop of Milan. He appreciates the earthly joy, drawing from ordinary, earthly life, but beyond it he submits the spiritual joy, ,joy of the heart" (iucunditas cordis), which comes from God, the Giver of wisdom.

\footnotetext{
${ }^{53}$ Por. tenże, Epistula 1, 6, SAEMO 19, 24, BOK 9, 33.
} 
